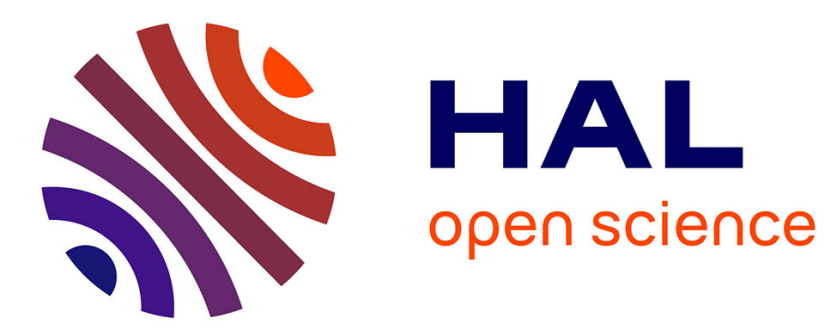

\title{
HIGH POWER LASER DIODES
}

G. Volluet, G. Marquebielle

\section{To cite this version:}

G. Volluet, G. Marquebielle. HIGH POWER LASER DIODES. Journal de Physique IV Proceedings, 1991, 01 (C7), pp.C7-781-C7-781. 10.1051/jp4:19917208 . jpa-00250915

\section{HAL Id: jpa-00250915 https://hal.science/jpa-00250915}

Submitted on 1 Jan 1991

HAL is a multi-disciplinary open access archive for the deposit and dissemination of scientific research documents, whether they are published or not. The documents may come from teaching and research institutions in France or abroad, or from public or private research centers.
L'archive ouverte pluridisciplinaire HAL, est destinée au dépôt et à la diffusion de documents scientifiques de niveau recherche, publiés ou non, émanant des établissements d'enseignement et de recherche français ou étrangers, des laboratoires publics ou privés. 


\section{HIGH POWER LASER DIODES}

G. VOLLUET and G. MARQUEBIELLE

THOMSON HYBRIDES, BP. 10, 29 avenue Camot, F-91349 Massy cedex, France

Rare earth ions can be efficiently pumped by Ga Al As/ Ga As laser diode emitters. For exemple the $808 \mathrm{~nm}$ wavelengt fits well with a strong absorption line of $\mathrm{Nd}$ ion in YAG material to implement Diode Pumped Solid State Lasers.

Recent improvements in structures, epitaxial conditions and technological process have proved the feasability of high power Ga Al As / Ga As laser diodes with strong efficiency.

In this paper, we will describe recent work done at THOMSON and we will present the main results measured on laser diode bar array structures $(1 \mathrm{~cm} l o n g)$. More than $10 \mathrm{~W} \mathrm{CW}$ are obtained with bars formed by 30 arrays of 10 coupled stripes. Optical to electrical efficiency is $35 \%$. Linear characteristics have been measured over $60 \mathrm{~W}$ of peak power in a QCW operating mode (pulse width $=200 \mu \mathrm{s}$ and a repetition rate of $50 \mathrm{~Hz}$.

Wavelength characteristics and thermal behavior will be analysed as a function of geometries and submounts.

Then we will discuss the possibility of more advanced monolithic structures for high optical power density. 